DOI: $10.30525 / 978-9934-588-61-7-6$

Gusarova S. A.

Doctor of Economical Sciences, Associated Professor, Leading Researcher at the Department of World Economy Plekhanov Russian University of Economics

\title{
PARTICIPATION OF BRICS COUNTRIES IN INTERNATIONAL TRADE: CHALLENGES AND INCENTIVES
}

\section{Summary}

Results of the research of BRICS (Brazil, Russia, India, China, South Africa) trade with the other countries of the world are provided in the paper. Trade cooperation of «five» states can enhance their economic development. The role of BRICS trade cooperation is not enough reflected in the economic researches. The carried-out analysis allowed to reveal the main problems of BRICS trade cooperation with the other countries of the world. Author suggests Regression Model for definition of the degree of interrelation of trade cooperation of BRICS countries and growth of their GDP. Trade cooperation of «five» states exerts very strong impact on the development of their economies.

\section{Introduction}

In the Strategy for the Development of Economic Cooperation of BRICS Countries, one of the priority areas of their interactions is the trade and investment [1].

The expansion and development of foreign trade allows BRICS countries to import foreign materialized technologies (for example, modern machinery and equipment) and non-materialized (clean) technologies (such as, licenses, patents, know-how, trademarks, etc.) [2].

Most of BRICS countries (four out of five) are global players in global commodity markets. China is the world's largest exporter and importer of various goods, Brazil, India, and Russia are among the thirty leading world trading powers. Data from the international organizations indicate that trade within the BRICS is showing a higher pace than the global average.

The volume of foreign trade in goods in the world economy increased 3.2 times in 2001-2018, while the trade between BRICS countries and other countries of the world increased much more -6.8 times. 


\section{Part 1. Trade Cooperation of BRICS countries with the other countries of the world}

The share of BRICS countries in the global foreign trade in goods increased from $7.4 \%$ in 2001 to $17.3 \%$ in 2018. Share of China was $11.8 \%$, India - 2.1\%, Russia - 1.8\%, Brazil - 1.1\%, South Africa - 0.5\% [1].

The trade balance of BRICS countries was generally positive and increased by 6.9 times in 2001-2018 (up to 437 billion USD). However, a negative value of the trade balance for a long time was noted in India and South Africa (in 2014 in Brazil too). This indicates the insufficient level of competitiveness of export industries in the economies of these countries, which led to the devaluation of national currencies. India's trade deficit has been observed since 1977 (in 2014-2018 it was the largest among BRICS countries, mainly due to the import of expensive raw materials). In 2018, the trade deficit in India amounted to 186 billion USD [1].

The positive trade balance of China grew 16 times in 2001-2018, and 4.6 times in Russia. The difference between export and import of goods in 2018 amounted to $3.1 \%$ of Brazil's GDP, $2.6 \%$ of China's GDP and $12.8 \%$ of Russia's GDP. To overcome difficulties, BRICS countries are interested in increasing the export of products and ensuring a surplus in the trade balance.

In 2020, the coronavirus pandemic exacerbated many trends, which had developed earlier. COVID-19 suspended the chain of trade operations. This was a challenge and an incentive for improving trade relations between countries. «Five» states at this difficult time demonstrate an example of partnership and support.

In 2018, BRICS countries accounted for $18.5 \%$ of world exports of goods and services (versus $8.1 \%$ in 2001), including China - 13.2\%, Russia $-2.1 \%$, India $-1,7 \%$, Brazil $-1.3 \%$, South Africa - 0.5\%. In 2001-2018, China's commodity exports increased 8.5 times, Russia -3.5 times, India -6.8 times, Brazil - 3.7 times, South Africa - 3.4 times.

The TOP 30 largest exporters of goods in the world included the following BRICS countries: China was on the 1st place, Russia was on the 16th place, India was on the 20th place, Brazil was on the 26th place. South Africa was not on this list.

Some BRICS countries were among the TOP 10 largest exporters of various types of goods in the world: agricultural products, oil, gas and mining products, office and telecommunication equipment, iron and steel, chemical products, automotive products, textiles and clothing.

In 2018, three BRICS countries were among the Top 10 exporters of agricultural products in the world - Brazil was on the 3rd place $4.9 \%$ of world exports of this type of product, China - on the 4th place (4.8\%), India was on the 9th place $(3.1 \%)$.

There were two BRICS countries among the TOP-10 world exporters of oil and gas, as well as mining products, (which in 2015-2016 encountered problems of a significant reduction in prices for these types of goods). Russia ranked 
second in the world (153 billion USD, or $7.4 \%$ of world oil and gas exports, as well as mining products). China was on the 9th place in the world (51 billion USD, or $2.4 \%$ of world exports). In 2018, Russia ranked first among oil exporting countries -9.3 million barrels of oil per day (12.8\% of world exports). China was the world's leading oil importer in $2018-11.0$ million barrels of oil per day ( $15.5 \%$ of world imports).

In order to determine how oil export and import influenced the development of the economies of some BRICS countries, we conducted a regression analysis for 2008-2018, which allowed us to calculate the following regression equations for the BRICS countries [1]; [3]:

Brazil $\mathrm{y}=29.5529 \mathrm{x}+132.4042$

Russia y $=8.2454 \mathrm{x}+639.7151$

India $\mathrm{y}=1.5844 \mathrm{x}+1867.2686$

China $\mathrm{y}=31.793 \mathrm{x}+3907.7239$

South Africa $y=0.2024 x+299.8786$

The study led to the conclusion that an increase in the volume of trade of oil in Brazil's by 1 USD leads to an average increase in its GDP by 29.6 USD. In Russia, this figure was 8.2 USD, in India - 1.6 USD, in China 31.8 USD, in South Africa - 0.2 USD.

Four BRICS countries were among ten world leading exporters of iron and steel. China's exports of iron and steel in 2018 amounted to $16.4 \%$ of world exports of the product - the 2nd largest in the world, and Russia $-4.2 \%$ of world exports of this type of product - the 6th place in the world. India was on the 8th place in the world. Brazil moved from the 11th place in 2014 to the 9th place in $2018-2.4 \%$ of world exports of iron and steel.

China and India entered the TOP 10 world exporters of chemical products in 2018. China was on the 3rd place in the world (6.8\% of world exports of this type of product). India improved its position from the 10th place in 2014 to the 8th place in the world in 2018 (2\% of world exports).

China took the 1st place among the Top 10 world exporters of office equipment and telecommunication equipment (32.3\% of world exports of this type of product).

Among the ten leading world exporters of automotive products, China in 2018 was the seventh-largest in the world (3.6\% of exports of this type of product), and India - on the 10th place ( $0.9 \%$ of world exports). China and India were also among the ten largest world textile exporters. China ranked first in the world $-37.2 \%$ of world textile exports), India - the 3rd place $7.1 \%$ of world exports. Among the world exporters of clothing, China was on the 1 st place $-36.4 \%$, India - on the 5 th place $-4 \%$. BRICS countries were the leading exporters and importers of goods in the global economy in 2018. Among the global exporters of goods, China was on the 1st place, and on the 5 th place among exporters of services in the world; Russia occupied 16th and 25th place respectively; India - the 20th and 9th place; Brazil - the 26th place (country was not included in the list of 30 leading exporters of world 
services); South Africa was not included in the list of 30 leading exporters and importers of goods too (Table 1).

Table 1

BRICS countries in the TOP-30 leading exporters and importers of goods in the world in 2018 [1]

\begin{tabular}{|l|c|c|c|c|c|}
\hline \multicolumn{1}{|c|}{ Indicators } & Brazil & Russia & India & China & $\begin{array}{c}\text { South } \\
\text { Africa }\end{array}$ \\
\hline $\begin{array}{l}\text { The volume of exports of } \\
\text { goods, billion dollars }\end{array}$ & 240 & 452 & 322 & 2487 & 94 \\
\hline Place in the world & 26 & 16 & 20 & 1 & - \\
\hline $\begin{array}{l}\text { Volume of imports of } \\
\text { goods, billion dollars }\end{array}$ & 181 & 240 & 508 & 2136 & 93 \\
\hline Place in the world & - & 25 & 9 & 5 & - \\
\hline
\end{tabular}

The volume of imports of goods by BRICS countries from the other countries of the world increased in 2001-2018 by 7.3 times. The volume of imports of goods by India increased over this period by 10 times to 508 billion USD, China - by 8.8 times to 2136 billion USD, Russia by 4.4 times to 240 billion USD, South Africa - by 3.6 times to 93 billion USD, Brazil - 3.2 times to 181 billion USD. The volume of imports of South Africa (not included in the TOP-30 world importers of goods) in 2018 was 93 billion USD.

In 2018, the volume of imports of goods by Russia amounted to 240 billion USD. In the import structure, the share of machinery and equipment was $51.8 \%$, chemical products $-18.3 \%$, food products $-11.5 \%$, textiles and training $-5.8 \%$, metals and products from them $-5.7 \%$, etc. [4].

The share of BRICS countries in global imports of goods increased from $6.8 \%$ in 2001 to $16.1 \%$ in 2018 , including China's share of $10.9 \%$ (the 2 nd place in the world), India $-2.6 \%$ (the 11th place in the world), Russia $-1.2 \%$ (the 20th place in the world), Brazil $-0.9 \%$ (the 28th place in the world), South Africa $-0.5 \%$ (the 34th place in the world).

In 2017, the volume of imports of services of BRICS countries included in the TOP-30 world importers of services was as follows: China - 464 billion USD (the 2nd in the world), India - 150 billion USD (the 10th in the world), Russia -87 billion USD (the 16th place in the world), Brazil -66 billion USD (the 23rd place in the world).

To determine the degree of openness of the economies of BRICS countries, an analysis of changes in their export quota (the ratio of the volume of exports of goods and services to GDP - one of the indicators of the openness of the economy) was made. The largest export quota in 2018 was in Russia (27.3\%), in South Africa (25.4\%), and in China (18.3\%). In India it was $11.3 \%$, in Brazil - $12.7 \%$. 
In China, there was a change in course from an export orientation to an increase in domestic consumption. This policy made it possible to ensure the above countries reduce the dependence of their economies on foreign consumption, and avoid vulnerability to the external environment.

As for the change in the import quota of BRICS countries (the ratio of imports of goods and services to GDP) in 2018 this indicator was the biggest in South Africa - 25.1\%. In India, it was $18.7 \%$, in China - 15.7\%, in Russia $-14.5 \%$, in Brazil $-9.6 \%$.

The decrease in this indicator (primarily in Russia, mainly due to the sanctions imposed by the USA, some EU countries and several other states) was associated with the implementation of the import substitution policy.

The leading exporters of significant volumes of goods to BRICS countries (including high-tech) are companies from the USA, Germany, France, Great Britain, Japan, and other countries.

Foreign companies exported high-tech products to BRICS countries, primarily to China. The volume of exports of goods from the USA to BRICS countries in 2018 amounted to 205.4 billion USD [1], including high-tech goods (their share was 26.1\%). In 2001-2018, the volume of US exports to BRICS countries grew 4.9 times, the largest share of their exports fell to China $(58.5 \%)$.

The volume of US exports to Russia in connection with the imposed sanctions decreased over 2013-2015 by almost half (47.7\%). The United States was in the 5th place among Russia's trading partners. In 2018, the value of the exported goods from the United States to Russia was 6.7 billion USD [1].

In early 2018, the United States declared China's trade policy «unfair», leading to a trade war between two powers. The US has set itself the goal of discouraging China from gaining leadership in the global technology sector. The United States accuses China of stealing American intellectual property.

In the United States, a list of 1300 Chinese goods was published, with a total value of about 50 billion USD per year, which was proposed to be taxed at $25 \%$ (aircraft parts, household appliances, medicines, manufacturing and medical equipment, chemical products, robotics, satellites, LED lamps, dishwashers, televisions, etc.). The United States imposed duties on imports of steel $(25 \%)$ and aluminum (10\%) from China, Russia, and several other countries.

China, in response, announced the introduction of import duties of $15-25 \%$ on 128 types of key US export goods at 3 billion USD per year (Boeing planes, soybeans, pork, grape wine, some types of fruits, berries, and nuts). Russia has a chance to oust a number of the American agricultural products from the Chinese market.

In 2018, Germany exported 179 billion USD worth of goods to BRICS countries (5.8 times more than 2001), including 39.2 billion USD worth of high-tech products (its share was 21.8\%). The largest share of exports of 
goods from Germany among BRICS countries fell to China (61.7\%). Russia was In the 2nd place (17.5\%). The volume of German goods exported to Russia in connection with the imposed sanctions decreased in 2016 compared to 2013 by more than half (by 51.5\%). Germany was in the 2 nd place among Russia's trading partners. In 2018, trade between Russia and Germany amounted to 31.4 billion USD [1].

In 2018, Japan exported 168.9 billion USD [1] worth of goods to BRICS countries, including high-tech goods (their share was 27.2\%). In 2001-2019, the volume of exports of Japanese goods to BRICS countries grew by 17.4 times. Japan exported the largest volume of goods to China (85.3\%).

Exports of Japanese goods to Russia decreased by more than a third in 2016 compared to 2013 due to the sanctions imposed (by 37\%). Japan was on the 8th place among Russia's trading partners. In 2018, trade between Russia and Japan amounted to 7.3 billion USD [1].

In 2018, France supplied goods to BRICS countries for 44.7 billion USD (4.8 times more than in 2001) [1], including the export of high-tech French goods to BRICS countries (38.3\% French exports of goods to BRICS countries). France supplied the largest volume of goods to China (55\%).

The volume of French exports to Russia was reduced in 2013-2016 due to the sanctions imposed by $47.1 \%$. France was on the 10th place among Russia's trading partners. In 2017, trade between Russia and France amounted to 6.3 billion USD.

The volume of exports of the UK goods to BRICS countries in 2018 amounted to 43 billion USD, including high-tech goods -8.7 billion USD (20.2\%). In 2001-2018, the UK increased its exports to BRICS countries by 4.2 times. The UK exported the largest volume of goods to China (64.4\%). The UK exports to Russia decreased over 2013-2016 due to sanctions by more than half (56.8\%).

The volume of foreign trade turnover of BRICS countries with other countries of the world has increased 7.3 times in 2001-2018 (up to 6,753 billion USD).

To determine the impact of international trade on the growth of the economies of BRICS countries, the author conducted a regression analysis between the volume of foreign trade turnover of each of BRICS countries with other countries of the world and the GDP of BRICS countries. The highest regression coefficient was obtained in Brazil.

The following regression equations were obtained:

- Brazil: $Y=5.6531 \mathrm{x}-130.4427$

- Russia: $Y=2.7909 x-159.5175$

- China: $Y=2.7242 \mathrm{x}-1098.1708$

- India: $Y=2.3084 x-392.1452$

- South Africa: $Y=1.6359 x+65.3617$ 
The analysis allowed to determine the regression coefficients and draw the following conclusions: an increase in the foreign trade turnover of Brazil with other countries by 1 USD leads to an average increase in Brazil's GDP by 5.7 USD; in Russia - by 2.8 USD; in China - by 2.7 USD; in India - by 2.3 USD; in South Africa - by 1.6 USD.

BRICS countries are actively engaged in the purchase of materialized foreign technologies, which contributes to the modernization of production, the formation of their national innovation systems. A significant share in the world import of high-tech equipment was accounted by China (12.7\%), India's share was $1.8 \%$, Brazil's - 1.1\%, Russia's - 0.9\%, South Africa's $0.4 \%$. More than half of the high-tech products imported by BRICS countries from other countries of the world (51.4\%) accounted for the most modern and innovative products (electronic goods and spare parts for them). The import of high-tech products allows BRICS countries to receive advanced technologies from developed countries.

An important role in the economic development of BRICS countries is played by modern information and telecommunication technologies. The share of telecommunication equipment in the total imports of machinery, equipment, and vehicles by BRICS countries amounted to 9.7\%. The largest volume of this type of equipment was imported by China (51.2\% of the total imports of telecommunication equipment by BRICS countries).

Three-quarters of the high-tech products among BRICS countries were also imported by China (75.2\%), which was 7 times more than imports of this type of product by India, 12.1 times - by Brazil, 13.7 times - by Russia, 32.6 times - by South Africa. Most of the imports of machinery, equipment, and vehicles by BRICS countries are related to high-tech products $(94 \%)$.

Correlation analysis of the close relationship between the volume of imports of high-tech products by each BRICS country from other countries of the world and their GDP for 2001-2018 revealed a very close relationship between these parameters in all BRICS countries: in Russia (0.9964), in Brazil (0.9780), South Africa (0.9737), India (0.9631), and China (0.9466), which allows us to conclude that there is a high degree of tight connection between the growth of BRICS economies and the import of high-tech foreign goods.

The acquisition of high-tech equipment allows catching-up economies to receive new technologies from developed countries and to focus their research and financial resources on the development of those technologies that will contribute to the innovative development of the country.

Not only materialized, but also non-materialized (clean) technologies (patents, licenses, know-how, trademarks, etc.) are of great importance for the development of the economies of BRICS countries. Obtaining technologies in their pure form, being more efficient than buying machinery and equipment, 
allows to save money and direct scientific personnel to research and develop other modern technologies and introduce them into production.

Despite the growth of imports of intellectual property, its volume in BRICS countries is insufficient. More than half of all payments by BRICS countries for obtaining intellectual property in 2018 were made by China (6.8\% of global payments), Brazil accounted for $1.5 \%$, Russia $-1.5 \%$, India $-1.5 \%$, South Africa $-0.5 \%$.

The leading clean technology exporters in the global market - the United States 39.2\%), the Netherlands (12.3\%), Japan 11.5\%).

The share of applications from BRICS countries in the global economy for obtaining trademarks was prevailing (65.9\% of all applications submitted by BRICS countries). A small proportion of the number of applications filed by BRICS countries for obtaining patents for inventions (23\% of all applications filed by BRICS countries) indicates that «five» countries independently develop simpler types of clean technologies and need to import more complex clean technologies.

The increase in the number of patents and licenses for obtaining highperformance technologies, as well as the development of clean technologies in BRICS countries should be connected with the use of scientific developments of industry research institutes conducting research in the field of advanced technologies in leading sectors of the economy, contributing to the development of interaction between science and production. BRICS countries not only buy but also deliver modern clean technologies to the world market. However, the volume of imports of clean technologies in 2018 was 14 times higher than the volume of their exports.

A correlation analysis of the close relationship between the volumes of imports of clean technologies (patents, licenses, know-how, etc.) by BRICS countries and their GDP for 2001-2018 revealed that a high correlation is observed in almost all BRICS countries.

A very close relationship in these parameters was established in China (0.9911), in South Africa (0.9670), in India (0.9478), in Russia (0.9286). In Brazil, the relationship between these indicators was noticeable (0.6737). The above data indicate that there is a fairly close relationship between the national economies of BRICS countries and the inflow of clean technologies into these countries. The economic development of BRICS countries, the transition to the next technological order is associated with the arrival of modern foreign technologies to them, both in materialized and in pure form.

Obtaining the most advanced technologies in the global economy is complicated by the fact that the developed countries that own them primarily supply their branches with these technologies, gaining a competitive advantage. Only later, after they lose this advantage, new technologies exported to other states. Thus, technologically backward countries are doomed to adapt well-known technologies. It is necessary to focus on research and development that can pull a chain of interconnected technologies 
aimed at accelerating the development of BRICS countries. The successes achieved in the imitation and adaptation of modern technologies by BRICS countries, as well as in the development of their original (or improved) technologies, expand the possibilities of cooperation within the group and access to new technological breakthroughs.

\section{Part 2. The development of e-commerce in BRICS countries}

The development of e-commerce has an impact on improving the efficiency of trade cooperation between countries. The globalization of the digital economy is fundamentally changing the relationship between countries. In the future, e-commerce may become one of the most important areas of the mutually beneficial cooperation of BRICS countries, contributing to the further growth of their national economies.

E-commerce is important for all BRICS countries. In 2017, the ministers of the countries adopted the «BRICS E-commerce Cooperation Initiative» of BRICS countries [5]. «Five» states introduce mainly the following business models: B2B (Business-to-Business); B2C (Business-to-Consumer); $\mathrm{C} 2 \mathrm{C}$ (Consumer-to-Consumer); B2G (Business-to-Government), G2B (Government to Business).

The largest Chinese online sales company is the «Alibaba Group», founded in 1999. «Alibaba» is a leader in the world electronic commerce, provides its customers with B2B and B2C business models. Starting with the sale of local products, the company has become a global leader in online marketing. Clients buying goods on the «Alibaba» platform are more than 65 million registered users from 240 countries and regions of the world [6]. In sales of goods via the Internet, «Alibaba» overtook American companies (Amazon, eBay). In addition to e-commerce, the company provides search engine services, cloud computing data services, electronic payments. The company accounts for $63 \%$ of China's electronic commerce. "Alibaba» provides infrastructure and technological products to sellers on the Internet - small and medium enterprises, representatives of various brands.

In 2012, «Alibaba» entered the Russian market (under a partnership agreement with the Qiwi payment system). In 2013, the company provided an opportunity for customers to pay for goods online using the Web Money Transfer system. In 2014, an agreement was concluded between «Alibaba» and «Yandex.Money». Russian buyers were able to pay for goods using Yandex wallets. In 2014, the company, having carried out an initial public offering of its shares (IPO) on the New-York Stock Exchange (NYSE), raised 25 billion USD.

Among the Chinese companies working on the Internet using the $\mathrm{B} 2 \mathrm{C}$ business model, one can also single out Jingdong (JD.com Inc. - Jingdong Mall), which is the largest Chinese company of revenue -11.6 billion USD in 2016. Jingdong is the fifth largest e-commerce company in the world [7]. For global expansion in 2015, the company launched its website in Russian. 
Using a convenient interface, the company offers users a wide selection of high-quality products. The parent company is located in Beijing, with branches in Shanghai and Guangzhou. The company has qualified personnel (100 thousand sellers work in the online market) and extensive trading infrastructure, including a «last mile» distribution network close to real buyers of products. The company has created its own electronic sales technology platform.

Global Rus Trade Company [8] - is the leading Russian cross-border ecommerce platform operating based on the B2B model. The company offers customers to start trading with trusted customers in three clicks (search for partners, negotiating, closing deals). The goal of Global Rus Trade is to help increase the turnover of 16.5 thousand product exporters and support small and medium enterprises in achieving high export potential. Only $0.28 \%$ of the Russian small and medium enterprises, according to the Ministry of Economic Development, are currently exporters of products, but at the same time they provide $6 \%$ of the country's exports. Global Rus Trade is a leading unique platform for the electronic trading of goods that is exported goods to the BRICS, Southeast Asia and Latin America. The export products of the Russian small and medium-sized enterprises to the «five» states include, for example, bifidobacteria, industrial equipment, building materials, electrical equipment, water filters and other goods.

Many BRICS countries are interested in increasing trade with Russia. For example, China views trade with Russia as an important project to enter the European market by the implementation of the «One Belt - One Road» Initiative. About $90 \%$ of online foreign purchases by the Russian Internet users are accounted for by supplies of products from China. The Chinese scientific and technical company Wanji, which has been working since 2014 in organizing a system for storing and delivering goods to Russia, has created a large warehouse in Russia for the development of e-commerce.

Since 2017, Russian consumers have the opportunity from the Yandex. Market (B2C business model) to purchase more than 50 thousand products from various Chinese manufacturers (Gearbest, JD.com, Umkamall, Intmall and others). Delivery and tracking are free. In 2018, Odnoklassniki social network introduced a marketplace (a fully integrated store in a social platform) for trading goods from China (placing orders and paying for goods) based on flash sales (selling popular goods).

On 2018, the largest online store in Russia was the company Ulmart (Ulmart.ru), sales of which amounted to 38.6 billion RUB. The company, introducing the $\mathrm{B} 2 \mathrm{C}$ model, sells online smartphones and gadgets, computers, televisions, cameras, office equipment, clothes, shoes, etc. [9]. In 2017, the volume of the Internet trading market in Russia increased to 1.04 trillion RUB, the volume of cross-border transactions amounted to 374.3 billion RUB (36\%) [10], most of which came from the purchase of Chinese goods by Russians. 
PetroCosm Corporation, the Brazilian leading B2B e-commerce company for the oil and gas industry, has set up a joint venture with one of the three largest oil companies in Latin America, Petrobras. The organization of this joint venture will contribute to the development of the Brazilian digital market for the purchase of oil and gas products, which will affect the reduction of operating costs of Petrobras. PetroCosm Corporation provides Petrobras and its Latin American partners with a fully integrated set of solutions for the supply chain on the Internet, including the opening of the Internet Operations Center in Rio de Janeiro. In addition to content services, provided services for procurement, payment, logistics, etc.

The leading Brazilian online e-commerce company operating on the $\mathrm{B} 2 \mathrm{C}$ business model is a B2W Digital company, whose sales amounted to 10.3 billion BRL. The company was formed as a result of a merger (Americanas; Submarino - a leader in innovative technologies) [11]. It accounts for about half of the total online sales market in Brazil. To expand its multiple distribution channels, the company aims to compete with large traditional retail businesses. The company operates in Brazil, Argentina, Mexico, Chile. B2W Digital company plans to organize online trading in India, China, USA, Uruguay.

The expansion of e-commerce has recently received much attention in India. Over the past few years, more than 4 billion USD has been allocated for its development, including 1 billion USD invested by the Chinese company «Alibaba».

An important role in the development of e-commerce in India is given to the «IndiaMart» marketplace, an online platform that collects and organizes information about the goods and services of various Indian companies. The growth of electronic sales on this site is due to the simplification of the relationship between buyers and sellers. Buyers get the opportunity to choose different types of goods from different manufacturers in one place. On its WEB portal, the company provides business models B2B, B2C, C2C. The $\mathrm{B} 2 \mathrm{~B}$ business model helps to ensure communication between manufacturers and purchasers of various goods. By providing a mobile platform, «IndiaMart» promotes the development of large, medium and small businesses. The company «IndiaMart» is the second in the world (after the Chinese company «Alibaba») B2B platform.

In 2014, «IndiaMart» launched a special Tolexo electronic platform to simplify the activities of small and medium-sized enterprises. The company has 3600 employees, more than 3 million suppliers work with it, its products are bought in 200 countries of the world. Venture investors (Intel Capital, Amadeus Capital, West Bridge Capital, Quona Capital) invest in the development of the company [12]. To increase the efficiency of online payments, «IndiaMart» introduced its sustainable payment platform (pay.indiamart.com). The company has developed for its customers (among which more than 3 million sellers and 35 million registered buyers) a program 
of protection against the risk of non-payment (for suppliers) and the risk of not receiving ordered goods, or receiving goods of inadequate quality (for buyers). Risk reduction contributes to the development of small and mediumsized enterprises, simplifying their business. A pilot project providing an opportunity to reduce risks was launched by «IndiaMart» (in conjunction with ICICI Bank) in January 2017. Marketplace «IndiaMart» is the largest online market in India. The company was awarded in 2017 the Global Prize of the Summit on mobile applications in the «business» category.

Another Indian company, Snapdeal, is an online platform (which has implemented the B2B and B2C business, with more than 300 thousand small and medium-sized enterprises selling electronics, mobile phones, clothes and shoes, household goods, and other products.

There are more than 50 million small and medium enterprises in India. However, only $8 \%$ of retailers have opened their online stores. Moreover, $42 \%$ of these companies belong to the fast-moving consumer goods (FMCG) sector, for example, selling food, cigarettes, alcoholic beverages, $16 \%$ of the companies are retailers in the fashion sector, $12 \%$ sell household appliances and electronics.

South Africa is one of the largest B2C e-commerce market in Africa and among the regional leaders on the Internet, as well as in mobile telephony. In 2015, only half of the population of South Africa have access to the Internet and only a third of the Internet users made purchases online. In 2016, sales of electronic commerce in South Africa according to the B2C business model doubled and amounted to $1 \%$ of the total retail sales in the country. In South Africa, online shoppers for inexpensive goods (tickets, books, etc.) did not trust their counterparties.

To develop e-commerce and provide a wider range of goods and services, some large online sellers have joined forces (for example, Takealot.com, Kalahari.com). «Takealot» [13] offers for sale more than 9 million products, including household appliances, health and beauty products, household chemicals, books, toys, clothes, and shoes, etc. The company is one of the fastest-growing and most innovative e-commerce retailers on the African continent.

Another large online store in South Africa («Kalahari» company) sells books, films, games, e-books, and electronics on the Internet. «Kalahari» is a pioneer in South African e-commerce, offering a wide selection of products and high-quality services, makes home delivery, offers various payment options.

The combination of these e-commerce companies allowed them to compete successfully with local retail stores, as well as with foreign e-commerce companies («Amazon» and «Alibaba»). South Africa's online retail business accounts for only $1.3 \%$ of the country's total retail market. For comparison, in developed countries (the United Kingdom and the United States) the share of the retail e-commerce market is $14 \%$. 
The major players in the B2C market in South Africa are also online stores «Makro» - a seller of household appliances and electronics, food, drinks, and «Zando» - a seller of men's and women's clothing and shoes (more 550 brands). Marketplace South Africa, the B2B business model is a fastgrowing market, comprising 149.2 thousand registered members offering 34.1 thousand goods [14]. Online companies in South Africa sell leather, toys, equipment, food, electronics, computers, and health products.

The analysis revealed the advantages and barriers of electronic commerce between the «five» states, as well as the development of recommendations on the formation of an effective e-commerce platform for BRICS countries. The main advantages of the group's e-commerce are the creation of new jobs; increase in cross-border trade and cross-border payments; the opportunity to enter new markets; development of direct trade cooperation without intermediaries; improving the sectoral structure of trade; increase in volumes and growth rates of trade; expanding the scope of activities of small and medium enterprises in the international market; improving the level and effectiveness of trade cooperation between countries; cost reduction for the organization of trade interaction.

The main barriers to the implementation of international e-commerce between the «five» countries are: insufficient information on the possibilities of electronic commerce for business development; lack of a system of electronic payments between foreign legal entities; weak stimulation of ecommerce; insufficient penetration of the Internet into the sphere of small and medium-sized businesses in some of BRICS countries (for example, in Brazil and India); difficulties finding a reliable partner; weak trust in both suppliers and customers in online trading; linguistic and cultural differences.

To create an effective e-commerce platform for BRICS countries, it is necessary:

- to create a unified concept of electronic commerce;

- to integrate the e-commerce markets of BRICS group of countries;

- to standardize the legal, administrative and technical regulation in electronic commerce (in order to ensure a unified approach);

- to provide conditions for barrier-free regulation of e-commerce between countries of the group;

- to perform joint provision of security measures during the exchange of electronic documents, including the development of measures and ways to protect personal data in electronic commerce;

- to ensure between BRICS countries the availability of the exchange of data and information on the development of electronic commerce;

- to provide exchange of experience and technology in organizing the most successful online trading projects, popularizing the most effective electronic trading platforms; 
- to develop joint authentication technologies for cross-border electronic transactions;

- to develop methods for verification of sellers; creation of B2B platforms for doing business and partnerships with suppliers, contractors, and dealers and sellers;

- to create a roadmap in the field of e-commerce development between BRICS countries;

- to organize a single database of electronic commerce between BRICS countries;

- to create a database of reliable, trusted suppliers; development of an Internet resource for small and medium-sized businesses;

- to create of logistics hubs (electronic ports) to facilitate and accelerate the customs clearance of goods;

- to hold conferences on the development of international electronic commerce between BRICS countries.

The expansion of e-commerce will stimulate the growth of trade between the BRICS countries, which will affect the development of the economies of these countries.

\section{Conclusions}

The conducted research on participation of BRICS countries in international trade allows to make the following conclusions:

- Cooperation with developed countries allows BRICS states to receive high-tech products, which help to enhance the industrial structer of their economy, to develop high-tech production in their countries.

- The regression analysis proposed by the author confirms the significant impact of trade cooperation between the BRICS sates and the other states of the world on the growth of their economies.

- Further development of the trade relationship of the BRICS countries is associated with the development of electronic commerce.

- The analysis allowed the author to identify the main problems and prospects of the development of electronic commerce.

- The main directions of the trade development in the BRICS countries are increasing the share of the most high-tech goods in the import structure of the BRICS countries (information, telecommunication and electronic equipment); stimulation of the import of high-tech goods and innovative technologies (by establishing tax incentives and customs preferences); a decrease in the share of adapted modern technologies and an increase in the share of original technologies developed by the BRICS countries; expanding mutual cooperation within BRICS in high-tech sectors of the economy; more active use of the creation of production and trading Intra-BRICS networks. 


\section{References:}

1. UNCTADSTAT (2020). URL: http://unctadstat.unctad.org/wds/TableViewer/ tableView.aspx

2. Gusarova S. A. (2015) Rol' vneshneekonomicheskikh faktorov v razvitii innovatsionnoy sfery stran BRIKS: monografiya [The role of foreign economic factors in the development of the innovation sphere of the BRICS countries: monograph]. Moscow: MAX Press. (in Russian)

3. International Monetary Fund (2019) // World Economic Outlook. URL: $\quad$ http://www.imf.org/external/datamapper/NGDPD@WEO/OEMDC/ADVEC/ WEOWORLD

4. Federal'naya tamozhennaya sluzhba (2019) / Tamozhennaya statistika vneshney torgovli [Federal Customs Service (2019) / Customs statistics of foreign trade]. URL: http://www.customs.ru/index2.php?option=com_content\&view=article\&id= 26258:2019-\&catid=53:2011-01-24-16-29-43\&Itemid=1981 (in Russian)

5. BRICS 2017 China (2017) / BRICS E-commerce Cooperation Initiative. URL: $\quad$ http://www.ranepa.ru/images/media/brics/china2017/BRICS\%20E-commerce\% 20Cooperation \%20Initiative_final\%20(2).pdf

6. Alibaba Group (2020). URL: http://www.alibabagroup.com/en/about/overview

7. Mbaskool (2018) / Top-10 eCommerce Companies in the World. URL: https://www.mbaskool.com/fun-corner/top-brand-lists/17622-top-10-ecommercecompanies-in-the-world-2018.html

8. Global Rus Trade (2020). URL: https://www.globalrustrade.com/ru/about/

9. E-Pepper (2020) Reyting TOP-100 krupneyshikh internet-magazinov Rossii [Rating TOP-100 of the largest online stores in Russia]. URL: https://e-pepper.ru/news/reyting-top100-krupneyshikh-internet-magazinov-rossii.html (in Russian)

10. Assotsiatsiya kompaniy internet torgovli (2018) Oborot rossiyskogo rynka internetriteyla prevysil $1 \mathrm{trln}$ rubley [Association of Internet Commerce Companies / The turnover of the Russian Internet retail market exceeded 1 trillion rubles]. URL: http://www.akit.ru/оборот-российского-рынка-интернет-ри/ (in Russian)

11. B2W Digital (2016). URL: http://hotsites.b2wdigital.com/relatorioanual2016/ english/

12. IndiaMart (2020). URL: https://corporate.indiamart.com/about-us/

13. Takealot (2020). URL: https://www.takealot.com

14. New South Africa B2B Portal (2020) // Foreign Trade Online. URL: https://www.foreign-trade.com/wholesale/New-South-African-B2B-Portal_43644.html 